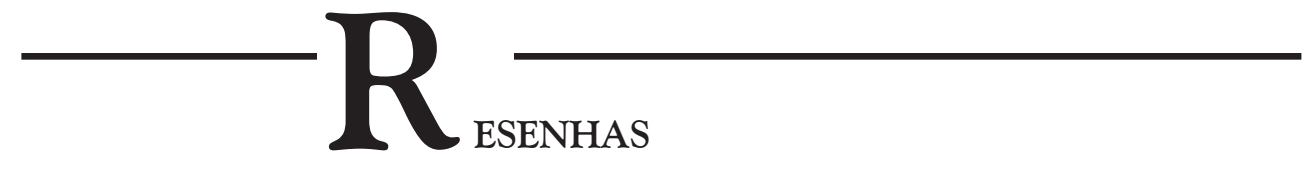

BARCELOS NETO, Aristóteles (dir.). Cruces vivas, cruces protectoras. Brasil: LISA, 2006, 28 min \& BARCELOS NETO, Aristóteles (dir.). El térremo y el señor. Brasil: LISA, 2005, $40 \mathrm{~min}$.

\title{
IMAGENS-CRUZES. A PROPÓSITO DE DOIS DOCUMENTÁRIOS SOBRE OS ANDES
}

\section{Renato Sztutman}

França Equinocial. Maranhão do século XVI. O padre capuchinho Yves d'Évreux tentava explicar para o grande pajé e chefe tupinambá Pacamont quem era aquele "morto tão bem feito e tão bem estendido n'este pau encruzado", ou seja, Jesus Cristo. Com efeito, d'Évreux gastou várias páginas do seu Viagem ao norte do Brasil, de 1616, descrevendo as conversas que mantinha com os tais "feiticeiros" e "principais" a respeito dos símbolos cristãos. Dizia ele àqueles que todas aquelas imagens não eram senão representações do filho de Deus, "feito homem no ventre da Virgem". Representações, vale frisar, já que os indígenas imaginavam estar muitas vezes diante de verdadeiros ídolos esculpidos em madeira, animados por espíritos poderosos.

Pacamont era repreendido pelo capuchinho justamente por atribuir à cruz no altar da capela intenção, ação e poder mágico; ou, para usar um termo de Alfred Gell $(1998)^{1}$, agência. D’Évreux lembrava que a cruz não passava de um 
símbolo, e que Nosso Senhor está no céu, distante. Repreender Pacamont era repreender a idolatria, essa prática que assombrava a Igreja Católica nos tempos da Contra-Reforma, visto que colocava em xeque a existência de um deus único e transcendente, feito carne apenas para purgar os pecados dos homens. Notese que pouco tempo antes, no século anterior, os católicos eram acusados pelos reformados, os huguenotes, de serem adeptos do canibalismo, uma vez que baseavam seu culto nos mistérios da Eucaristia, na transubstanciação da carne e do sangue de Cristo em, respectivamente, hóstia e vinho. Essas duas substâncias não estavam em relação de representação com o Senhor, aparentavam-se, isso sim, ao cauim alcoólico e à carne dos inimigos que tanto povoavam os festins dos antigos Tupi.

As imagens de Cristo, da Virgem e dos santos surtiram certamente mais efeito entre os povos do Altiplano do que entre os povos Tupi da costa brasileira. Apenas os primeiros eram afeitos a templos e a cultos dedicados a divindades esculpidas em pedra. $\mathrm{O}$ mais próximo da idolatria que se pôde suspeitar entre os Tupi foram os maracás, nos quais Hans Staden dizia habitar espíritos que falavam com os pajés quando de seus rituais algo macabros. No que dizia respeito aos padres, os Tupi se interessavam mais pelas suas palavras, pelas suas vestes e, por vezes, pelas suas ossadas. Já os povos andinos adoravam cruzes, e isso parece ter se mantido até os dias de hoje por mais que a sua sociedade tenha se transformado ao longo da história.

Como a gente de Pacamont, os povos andinos nunca deixaram de desconfiar da idéia de representação quando o assunto eram os símbolos cristãos. Cruzes e imagens de santos, longe de apenas representar divindades, apareciam a eles como objetos que fazem coisas, dotados de intenção, de ação, de poder mágico. Capacidade de garantir a fertilidade da terra, por exemplo. Em suma, esses objetos seriam como pessoas que, como tais, possuem um corpo que necessita ser vestido, paramentado. Esse investimento de agência nos símbolos cristãos - as cruzes, as imagens - é justamente o tema de dois documentários concebidos e dirigidos por Aristóteles Barcelos Neto, El terremoto y el señor, de 2005, e Cruces vivas, cruces protectoras, de 2006, ambos filmados nos Andes peruanos, mais precisamente, na cidade de Huaraz e seus entornos. Huaraz foi tragicamente destruída em 1970 por um terremoto e hoje em dia, refeita, vê-se ameaçada por um vulcão ainda em atividade. Nenhum desses eventos "naturais" é pensado pelos seus habitantes como livre da intervenção de divindades personificadas, dentre elas, aquelas que compõem o panteão cristão.

As festividades católicas são vividas fervorosamente pela população local. Nelas, imagens e cruzes saem para passear, no mais das vezes paramentadas para não dizer alimentadas. Dançarinos e músicos as celebram atraindo multidões. Isso gera um clima de tensão com os padres cristãos, muitos deles vindos de cidades grandes do país ou mesmo do exterior. Em uma cena de El terremoto y 
el señor, o padre exclama à multidão que adentra o santuário com seus trajes típicos e sua música: "Não podemos viver para as imagens! Imagens devem ser entendidas como um meio para se realizar a comunicação com Cristo Nosso Senhor, e não como um fim!" Enfim, o padre faz um discurso contra a idolatria, tal como aqueles proferidos na época da Conquista pelos colonizadores espanhóis. $\mathrm{Na}$ cena seguinte ao discurso do sacerdote (cujas palavras são tomadas tais quais as do chefe ameríndio caracterizado por Pierre Clastres), vemos pessoas acotovelarem-se bruscamente para tocar a imagem santíssima do Cristo de Mayo, o Cristo que permanece deitado e que só sai às ruas uma vez ao ano. Vemos também que o santuário - o Santuário de la Soledad - tornou-se espaço para uma festa tipicamente pagã. Em torno da imagem cobiçada vemos desenvolveremse coreografias e orquestras surpreendentes, que misturam elementos heterogêneos, como os chocalhos nos pés e as rabecas.

A tensão entre as práticas nativas e a Igreja Católica oficial parece também compor o tema central de Cruces vivas, cruces protectoras. $\mathrm{O}$ filme abre com o texto de 1661 de um espanhol que clama pela extirpação da idolatria no Peru: "Aconselha-se àqueles que levam a doutrina cristã aos índios procurar saber onde eles têm suas huacas e templos de adoração e fazer com que se desfaçam deles, colocando em seu lugar cruzes". Ora, as imagens que seguem evidenciam que o plano malogrou, e isso por uma razão simples: as cruzes não substituíram a idolatria, pelo contrário, elas foram incorporadas por ela. Em outras palavras, as cruzes foram ao longo dos séculos tragadas pelas festividades pagãs, como os seus ídolos de pedra elas foram dotadas de intenção, ação, poder mágico, agência. Foram reconhecidas como entidades, foram personificadas. Em Huaraz, isso redundou no embate entre o catolicismo oficial e a população local, de origem quíchua. Embate, poderíamos dizer, muito comum a toda a América Latina, onde se viu florescer enfaticamente um catolicismo sui generis, rústico quando não indígena.

Para cada documentário, uma festa. Em El terremoto y el señor, acompanhamos a história das imagens dos Cristos "duplos" e a procissão que se faz em torno de um deles, o Senhor de Mayo. A imagem sai da Igreja de Soledad para passear pela cidade e ser festejada. Em Cruces vivas, cruces protectoras, a data em questão é o carnaval e o movimento observado é oposto. Cruzes que protegem comunidades rurais são levadas pelos seus membros até a Igreja de Soledad para receberem uma benção. Para tanto, elas devem ser enfeitadas, vestidas e a sua benção inaugura uma série de festividades que compõem o carnaval andino que, embora menos conhecido mundialmente, tem ali um lugar tão central como aquele realizado no Brasil.

El terremoto y el señor conta a relação entre a procissão da imagem do Senhor de Mayo e o desastre ocorrido em 1970, desastre que incluiu a destruição da Igreja de Soledad. O filme abre com imagens da tragédia e passa, então, ao depoimento de Godofredo Zagarra, responsável pela restauração das imagens 
destruídas e pela reconstituição da imagem do Senhor de Mayo, que desapareceu durante o ocorrido. O santeiro conta, além disso, que é a imagem de Jesus de Soledad que impede que o vulcão entre em erupção e, com isso, destrua de vez Huaraz. Segundo Zagarra, para os huaracinos este Cristo é responsável por inúmeros milagres e cabe a ele presentear os homens com sua força divina e sua capacidade fertilizante. Para tanto, é necessário estabelecer com ele uma relação de reciprocidade.

Um ponto fundamental é o fato de o Senhor de Soledad ter um "duplo", o Senhor de Mayo, que permanece deitado em uma sepultura e apenas deixa essa posição no momento propício da procissão. Um comentário que lança luz a essa configuração é tecido por um homem ligado à igreja que diz que grande parte dos cultos andinos lida com dualidades e muitas das figuras míticas andinas são elas também duplas. O Cristo não poderia ter escapado a essa gramática mitológica e ritual. A procissão que se realiza em torno do Senhor de Mayo é acompanhada de grande festa, povoada por grupos de músicos e dançarinos denominados sascha, cujos membros são ricamente paramentados. Os sascha, esclarece outro personagem, são os responsáveis pela ponte entre o povo e o Senhor. Em todos os cantos que passam, eles são recebidos com comida e bebida.

Se em El terremoto y el señor, uma imagem do Senhor sai da igreja para ganhar as ruas, em Cruces vivas..., cruzes que protegem tais e tais comunidades rurais deixam o local onde permanecem todo o ano para receberem a benção na missa do santuário. Cruces vivas, cruces protectoras fala, portanto da relação entre campo e cidade e, ademais, da relação entre contexto familiar-comunitário e o catolicismo oficial, este que garante o reinvestimento das cruzes com o poder mágico que assegura o bom desenvolvimento dos plantios. A cruz que deixa a sua comunidade local é então paramentada, vestida como se fosse gente. Disso não escapa o trabalho das cozinheiras e dos músicos.

Por meio de uma longa exegese, uma personagem nos explica que as cruzes são como guardiãs de uma comunidade. Elas são erguidas sobre pedras e devem ser benzidas anualmente em paróquias. Muitas vezes elas aparecem "naturalmente", ou seja, as árvores trazem em si esculpidas formas de cruzes. Essas são designadas como "cruzes vivas", sendo igualmente objetos de culto. Nota-se portanto que o culto das cruzes foi de certo modo justaposto ao culto das huacas, divindades atribuídas a sítios naturais (montanhas, por exemplo) e a ídolos de pedra. A mesma personagem lamenta o fato de o padre ter antecipado essa espécie de peregrinação do campo a Huaraz. Anteriormente, isso ocorria no dia anterior ao início do carnaval, abrindo as festividades. Agora ocorre com uma semana de antecedência, já que os padres temem as "borracheras", bebedeiras características da celebração. Com efeito, em uma das cenas que sucedem à chegada das cruzes, ouvimos a voz do padre, em megafones, implorando aos jovens, enquanto atiram bolsas de água uns nos outros, que respeitem a cerimônia. 
Outra personagem, já bem idosa, lamenta também a antecipação da festa das cruzes e, além disso, a advertência vinda dos padres de que não é permitido aos católicos adorar aquelas imagens. Mas a senhora, perplexa, prefere concluir que é católica justamente porque pode adorar quaisquer imagens, sobretudo quando estas são trazidas à festa. Para ela, não há incompatibilidade entre ser católico e adorar imagens, pelo contrário, ela reconhece um potencial de "idolatria" no interior do próprio catolicismo. Eu diria que isso é muito revelador de ambos os lados.

Estes dois documentários de Aristóteles Barcelos Neto evidenciam que a penetração, desde o século XVI, do catolicismo nos Andes, habitado por populações indígenas na maior parte das vezes designadas como camponesas ou aculturadas, passa por apropriações locais dotadas de grande criatividade. Experimenta uma aclimatação no universo de religiões agrárias, nas quais poderes mágicos e não raro associados à fertilidade da terra são atribuídos a divindades, como o Sol. Enfrenta a subordinação a uma lógica sacrificial que, por meio de um ciclo de oferecimento de alimentos e de bebidas, acaba por estabelecer uma relação de reciprocidade entre homens e divindades. Em suma, ambos os filmes evidenciam como deuses cristãos e suas imagens vivas (e não meramente representacionais) são incorporados nessas redes de sociabilidade.

Colonização do imaginário indígena, como muito se disse? Apesar da pressão secular para que esses povos abandonassem suas práticas de idolatria, o que se vê é algo distinto. A idolatria absorve aqui a religião cristã criando um novo cristianismo. El terremoto y el señor e Cruces vivas, cruces protectoras falam sobre como se fazem novos cristianismos, novos catolicismos para além de sua base oficial, e isso passa pelo avivamento de suas imagens e de seu símbolo supremo, as cruzes. Indigenização do imaginário cristão, talvez seja esse o tema em pauta e talvez seja essa uma via interessante para continuarmos pensando - por que não? - a América Latina. Nesse sentido, também as imagens de Aristóteles Barcelos Neto - imagens-cruzes, diremos com menos ou mais credo - podem revelar a sua agência.

\section{Nota}

1 GELL, Alfred. (1998), Art and Agency. An Anthropological Theory. Oxford: University Press.

Renato Sztutman (sz.renato@gmail.com)

Professor do Departamento de Antropologia da USP, pesquisador do Núcleo de História Indígena e do Indigenismo (NHII/USP) e do Laboratório de Imagem e Som em Antropologia (LISA/USP). 